\author{
Małgorzata Wachowska \\ Uniwersytet Wroclawski \\ malgorzata.wachowska@uwr.edu.pl
}

\title{
The contribution of Polish technical thought to the quality of life in developed countries
}

Date of submission: 21st of January 2018; date of acceptance: 18th of February 2018

JEL Classification: F22, J61, O15, O33

Keywords: international transfer of knowledge, international migration of human capital, QOL, PCT patent applications, Poland

\section{Abstract}

The contribution of Polish technical thought to the quality of life in developed countries

Due to the fact that technological progress is an important factor influencing the quality of life, the purpose of the paper is to determine what is the contribution - measured by the number of inventions - of mobile Poles to increasing the quality of life of their host countries. The paper considers two fundamental questions: (1) how many inventions, including area of technology, Poles generate for the benefit of countries which they emigrate to and (2) what part of the inventive output of the host countries, including the area of technology, are inventions created by immigrants from Poland.

The paper uses the method of quantitative and qualitative analysis of patent applications made in the years 2004-2012 within the frames of international procedure by residents from developed economies of Europe, the United States and Japan (a total of 9 countries), which has made it possible to: (1) separate those applications in the case of which the creator of the technical solution is an immigrant from Poland and (2) determine the number of inventions created abroad by Poles for the benefit of their countries of destination.

The study involves individuals exceptionally endowed with high human capital who have especially contributed to technological changes occurring in the world, i.e. creators of inventions filed for patent protection within the frames of international procedure - The Patent Cooperation Treaty - who at the time of making the applications lived in the developed countries covered by the study and came from Poland.

The analysis of over 1700 PCT patent applications has made it possible to say that in the years 2004-2012: (1) Poles to the largest extent contributed to increasing the quality of life of Americans, for whom they created a total of 828 inventions, then Germans and Britons, whose inventive output they increased by 425 and 143 inventions, respectively, while their contribution to the improvement of the quality of life of the Japanese, Swedes or Finns was very small; (2) Poles to the largest 
extent contributed to increasing the quality of life of the inhabitants of developed countries by generating inventions in the following areas of technology: (a) chemistry; metallurgy and b) human necessities. Starting from 2009, the creative activity of immigrants from Poland is less and less related to the improvement of the quality of life of the inhabitants of their economies of destination.

\section{Introduction}

The quality of life is determined by many factors, frequently very individual ones. Technical development is, however, undoubtedly one of them. Ideas contained in inventions change the world and the ways of life of entire societies, resulting in an increase in the importance of inventors for the shaping of people's lifestyles and quality of lives on a global scale.

Although it is widely believed that it is mainly inventors from countries at the highest levels of technological development who contribute to improving the quality of life of the global population, it is increasingly pointed out, however, that inventors from countries remaining on the periphery of global technical development have also contributed in this regard. Moreover, it is increasingly emphasized that migration of inventors from these countries is important for the processes of transfer of scientific and technical ideas to developed countries, and consequently to raising the living standards of their inhabitants. These inventors include creators of technical solutions from Poland, who have long been part of the mainstream of American techniques without being inferior to representatives of other ethnic groups (Lotysz 2013), and more recently probably also to those from other countries of the world. This is because since 2004, when Poland joined the EU, Poles - including top specialists, scientists, or engineers - have emigrated en masse to the so-called EU-15 countries (Grabowska-Lusińska \& Okólski 2008; Okólski 2009; Lesińska et al. 2014; Kaczmarczyk 2015), using knowledge and skills acquired in their home country for the benefit of the host country's inhabitants.

Although there has been no shortage of Poles among inventors working in the United States, the number of their inventions remains undetermined. Similarly, there is still little knowledge of the scale and characteristics of Polish inventiveness in other parts of the world. The subject of the technical achievements of Poles abroad has been addressed by such researchers as Bolesław Orłowski, Stanisław Łotysz, and Stanisław Januszewski, but their works are rather analyses of specific examples of inventions or inventions from specific areas of technique, as they tend to focus on a selected country to which Poles emigrate and in most cases they discuss Polish inventiveness from a distant historical perspective. Admittedly, Stanisław Łotysz in his work Wynalazczość polska w Stanach Zjednoczonych (2013) presented inventive achievements of Poles in the United States by individual areas of technology and he also made an attempt to evaluate their "quality" in the economic, social, and political contexts, but neither he, nor the other researchers provide information on the volume of innovative output of Poles living abroad, 
including in relation to the number of inventions created by citizens of the host countries. In this perspective, the existing literature does not assess the contribution of Polish inventors to increasing the stocks of knowledge and thus also the quality of life of the inhabitants of their countries of destination.

The author of this paper tries to partly fill this gap by making an attempt to quantitatively determine the scale of the inventiveness of Poles abroad both in absolute terms and in relation to the scale of inventiveness of citizens of the host countries, as well as by focusing on a larger number of developed host countries. At the same time, she assumes that new ideas, including inventions, improve people's quality of life and the more there are of them, the higher the quality. The adoption of such an assumption, although it brings with it consequences related to the interpretation of results, is necessary due to the fact that "quality of life" is a very subjective concept. Therefore, it is difficult to indicate one measure of "quality of life" and it is even more difficult to clearly identify factors contributing to the improvement of the quality of life.

The purpose of this work is to answer the question of what contribution measured by the number of inventions - mobile Poles make to the quality of life of their host countries. The paper considers two fundamental questions: (1) How many inventions, including by area of technology, Poles generate for the benefit of countries to which they emigrate and (2) what part of the inventive output of the host countries are inventions created by immigrants from Poland.

The paper uses the method of quantitative and qualitative analysis of patent applications made in the years 2004-2012 within the frames of international procedure by residents from developed economies of Europe (Finland, France, the Netherlands, Germany, Switzerland, Sweden, the United Kingdom), the United States as well as Japan, which has made it possible to: (1) separate those applications in the case of which creator of the technical solution is an immigrant from Poland and (2) determine the number of inventions created abroad by Poles for the benefit of their countries of destination (details of the research approach are provided in the next section of the paper).

The study covers individuals exceptionally endowed with high human capital who have especially contributed to technological changes occurring in the world, i.e., creators of inventions filed for patent protection within the frames of international procedure - The Patent Cooperation Treaty (PCT) - who at the time of making the applications lived in the developed countries covered by the study and came from Poland.

\section{Research approach}

In this paper, in order to estimate the number of inventions created by Poles abroad, an analysis has been made of PCT patent applications filed by residents of nine selected developed countries (Finland, France, the Netherlands, Germany, 
Switzerland, Sweden, the United Kingdom, the United States, Japan) to which Poles emigrate.

PCT patent citations, handled administratively by the World Intellectual Property Organization (WIPO), are particularly valuable in identifying citizenship of individual creators of inventions and consequently their technical achievements. Contrary to patent applications of other types (within different domestic and regional procedures), they unambiguously reveal the citizenships of both the applicant as well as the inventors. Owing to this, these applications can be easily separated in which the creators of technical solutions are individuals of ethnic origin that is of interest to us. As a result of this, it is possible to precisely determine the number of inventions created by the citizens of a given country in a given place and time since both the date and place of the patent application are provided in patent documents (both PCT and all others). In a similarly easy way it may be determined for the benefit of whom (which country) the invention has been created because the patent documents show the country which the owner of the (future or granted) patent comes from.

Obviously, the other patent documents - domestic or regional ones - also make it possible to determine the number, year, and place of creation of the invention according to different criteria (e.g., the sex of the inventor, the area of technology of the invention, or the sector of the economy in which the invention has been reported), but they do not make it possible to sort the created inventions by citizenship of their creators since such information is not revealed in these applications. In the case of applications of this type, the nationality of inventors may be inferred only from the ethnic origin of their surnames, which obviously is conducive to making many errors.

It should be noted here that PCT patent applications reveal not so much the citizenship of the inventors as the citizenship of the applicants. However, due to the fact that up to 2012 it was required to list both all the inventors and the owner of the invention in the applicant field, specifying the citizenships of the inventors was also required. Unfortunately, because of changes in US patent law introduced on January 1st, 2012, only few PCT applications filed after 2012 include the nationality of the authors of inventions (Miguelez, Fink 2013) since only a few authors of inventions are added to applicants. Under the Leach-Smith America Invents Act (AIA), the United States has cancelled the requirement to list inventors as applicants in those PCT applications in which the United States is indicated as the so-called designated state in the application (i.e., the country in which the applicant considers seeking patent protection). It is the applicant's decision whether to name inventors together with the applicant. In practice, the majority of applicants have taken the opportunity not to list the authors of the inventions among the applicants. If we take into account that the coverage of a vast majority of "international patents" includes the United States, after 2012 PCT patents have become definitely 
less useful in research on the migration of inventors and its role in processes of knowledge transfer.

Due to the fact that this study uses WIPO knowledge stocks to determine the number of inventions generated by Poles living abroad in the years 2004-2012, the limitation related to the data after 2012 is overcome.

\section{The role of mobile inventors in improving the quality of life of the host countries - literature review}

Despite the rich literature on migration, there are relatively few works which discuss the problems of the contribution of spatially mobile individuals to increasing the stocks of knowledge of the host countries and consequently the quality of life of their inhabitants. Additionally, the majority of these focus only on the United States as the sole country of destination and they actually ignore the fact that other developed countries are also successful in attracting talents from abroad.

Such studies include Stephan and Levin (2001), who observe that individuals born abroad more than proportionately contribute to US science and are a source of strength and vitality of American science. Kerr (2009) reaches similar conclusions and he proves that immigrants contribute to a faster adoption of breakthrough innovations by Americans. The significant role of highly skilled immigrants in improving the quality of life of inhabitants of the United States is emphasized also by Hunt (2011) as well as Hunt and Gauthier-Loiselle (2010), who analyze the relationship between the presence of immigrants and the number of patents in the United States. Hunt (2011) observes that immigrants who visit the United States on a student visa or temporary work visa for the first time have an advantage over locals in the areas of patenting, commercialization, and licensing of patents and in this regard they surpass also immigrants who came later in their lives. Meanwhile, Hunt and Gauthier-Loiselle (2010) indicate that an increase in the number of immigrant scientists and engineers as well as an increase in the number of immigrants in colleges by 0.45 and 1.00 percentage points, respectively, increases the degree of patenting per inhabitant by $13 \%$ and $9-18 \%$, respectively.

The authors of studies who analyze the effects of influx of foreigners to national economies other than the United States speak in a similar spirit. While limiting her considerations to the German economy, Niebuhr (2010) observes that cultural diversity positively influences innovativeness and in this sense highly-skilled workers from abroad contribute to increasing the efficiency of regional R\&D sectors. Moreover, benefits from this diversity surpass negative results connected with the influx of foreigners. So far as Canada is concerned, Partridge and Furtan (2008) conclude that skilled immigrants from the United States and 
developed countries of Europe as well as developing countries of Eastern Europe and Asia increase innovativeness of Canada's regions. The research by Oettl and Agrawal (2008) is consistent with these results; focusing on mobile inventors from Germany, they argue that Canada gains their stocks of knowledge and skills.

Generally, the vast majority of works related to the effects of international migration of human capital on broadly understood innovativeness of host economies find a positive dependency between these two phenomena. It does not matter whether the research focuses on a particular host country (like the ones mentioned above) or a selected mobile ethic group and estimates its contribution to increasing the knowledge stocks of many different national economies (e.g., Edler, Fier \& Grimpe 2011). Findings of these studies fit in a generally prevailing view that countries benefit from the influx of high-class specialists, scientists and engineers, and the only unresolved question remains how large these benefits are and whether they outweigh the losses incurred from the presence of immigrants.

\section{The scale of inventiveness of Poles living abroad in developed countries: Research results}

The analysis of PCT patent applications in the case of which the invention creators were Poles living in 9 selected developed countries has shown that Poles are a quite active nation in terms of inventions when living abroad. In the years 2004-2012, they created a total of 1718 inventions in the countries covered by the analysis (Figure 1), which is actually 305 more than the number of analogous inventions they created for the benefit of their own country in the same period. Generally, the innovative activity which is higher abroad than in the home country is quite characteristic of the region of Central and Eastern Europe or developing (transforming) countries in general. Similar behavior patterns are characteristic e.g., of citizens of Slovakia, Ukraine, or Mexico (Wachowska 2017b, 2017c).

However, while the number of technical solutions created by Poles abroad increased each year until 2009, and thus inventors from Poland increasingly contributed to improving the quality of life of inhabitants of developed countries, a decreasing tendency in this regard may be observed from 2009. The number of inventions is followed by the share of inventions generated by Poles abroad in the inventive output of their host countries (Figure 2). Here, similarly, an increasing tendency may be observed until 2009 and a decreasing one in subsequent years, which might also be interpreted as a decrease in the importance of Polish technical thought for the improvement of the quality of life of inhabitants of developed countries.

Although it is difficult to give a clear reason for the drop in the number of inventions of Poles living abroad in both absolute and relative values without indepth research, the global crisis of 2008 seems to be significant here. On the one hand, it could force some Poles to return to their home country or re-emigrate to 
completely new parts of the world, and on the other hand, it could stop others from emigrating from Poland. This explanation is generally consistent with the research results, which indicate that the number of Polish PCT inventors in the countries that are the research sample in this study has decreased since 2009 (Wachowska 2017a). It is also consistent with the theory of the economics, in light of which the most-educated people generally are more willing to return to their home country than people without education or less-educated (Lee 1966).

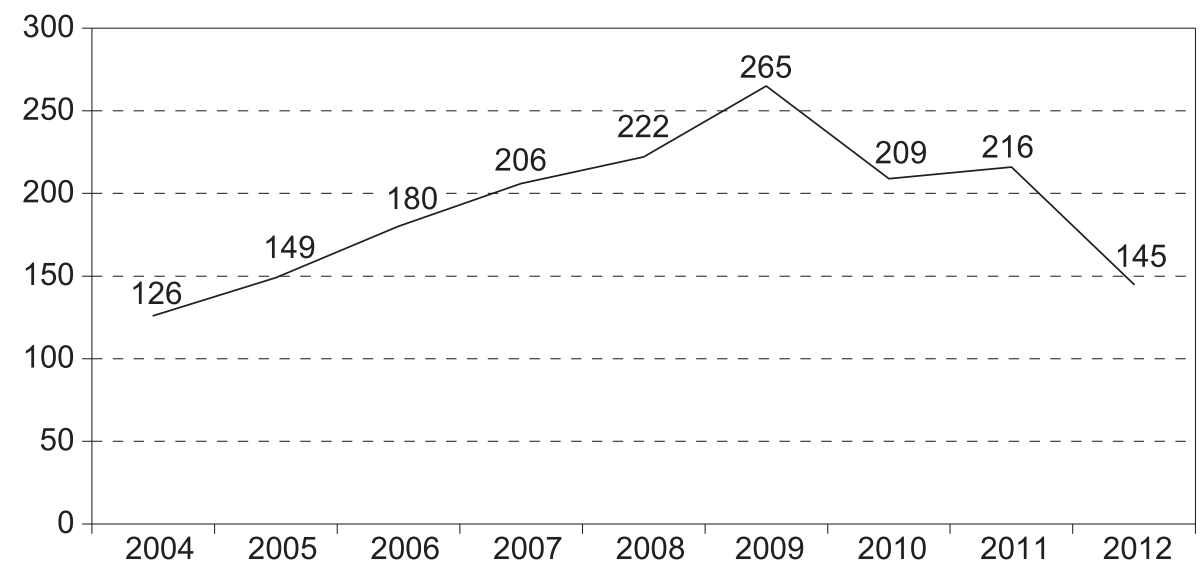

Figure 1. The number of PCT inventions created by Poles for the benefit of 9 developed countries under study in the years 2004-2012

Source: own work and calculations on the basis of an analysis of PCT patent documents.

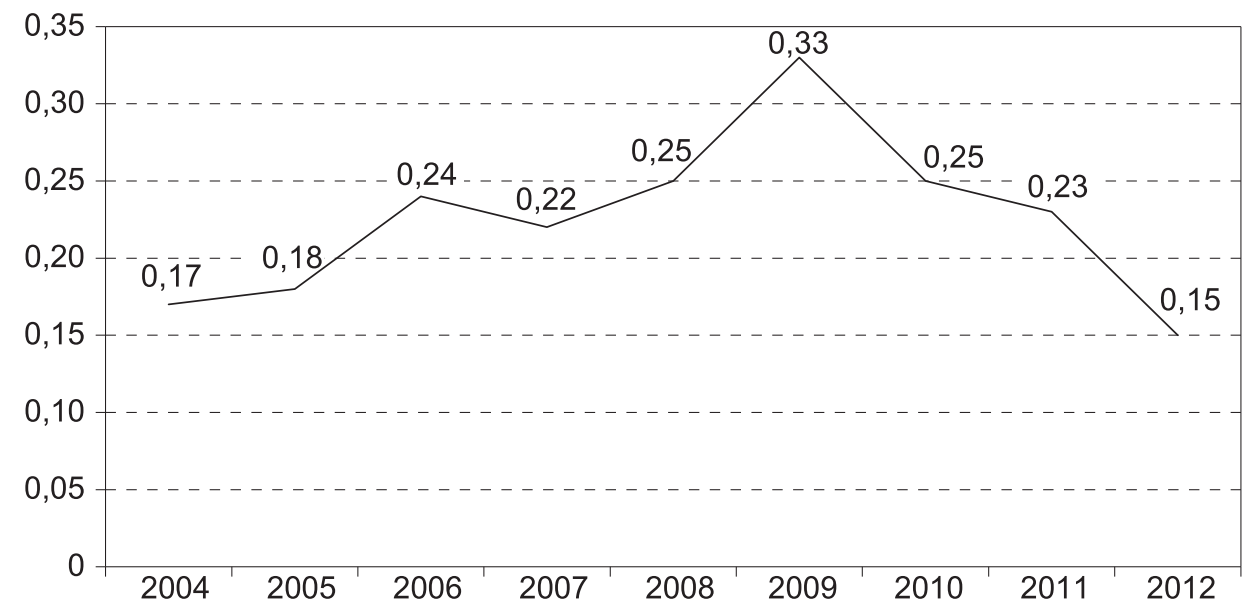

Figure 2. Share of "PCT inventions of Poles" in PCT inventions of residents of the host countries in the years 2004-2012

Source: own work and calculations on the basis of an analysis of PCT patent documents. 
Of the 9 countries covered by the analysis, the largest beneficiary of the presence of inventors from Poland in the years 2004-2012 continued to be the United States, where Poles created a total of 828 technical solutions. Germany followed suit with 425 inventions created by Poles and then the United Kingdom with 143 inventions. In other developed countries inventors from Poland marked their presence to a much lesser degree, creating fewer than 70 inventions in each (Table 1).

Just as domestically, also abroad in the years 2004-2012 Poles created largely inventions classified in the following areas of technology: (1) human necessities, usually from the area of medicine and (2) chemistry; metallurgy, with the difference being that domestically the inventions from the first area outnumber slightly the ones from the second area, whereas there is a reverse situation abroad (Figure 3). This means that the quality of life of the inhabitants of developed countries improves owing to various types of solutions coming from both these areas, although it should be emphasized that examples of individual countries are not consistent with the general picture (Table 2). For instance, Poles living in the Netherlands and Sweden mainly contribute to the following areas of technology: (1) physics and (2) electricity.

Table 1. The number of PCT inventions whose authors or co-authors are immigrants from Poland, in selected developed countries in the years 2004-2012

\begin{tabular}{r|r|r|r|r|r|r|r|r|r|r}
\cline { 2 - 11 } & CH & DE & FI & FR & GB & NL & SE & US & JP & Total \\
\hline 2004 & 9 & 23 & 1 & 2 & 10 & 12 & 3 & 64 & 2 & 126 \\
\hline 2005 & 3 & 29 & 0 & 3 & 7 & 19 & 3 & 82 & 3 & 149 \\
\hline 2006 & 6 & 38 & 0 & 7 & 12 & 24 & 1 & 90 & 2 & 180 \\
\hline 2007 & 5 & 50 & 4 & 7 & 10 & 16 & 2 & 108 & 4 & 206 \\
\hline 2008 & 8 & 55 & 5 & 5 & 23 & 11 & 0 & 115 & 0 & 222 \\
\hline 2009 & 8 & 82 & 2 & 8 & 16 & 12 & 2 & 131 & 4 & 265 \\
\hline 2010 & 11 & 79 & 6 & 5 & 12 & 7 & 7 & 81 & 1 & 209 \\
\hline 2011 & 10 & 51 & 3 & 12 & 23 & 7 & 12 & 94 & 4 & 216 \\
\hline 2012 & 9 & 18 & 1 & 8 & 30 & 9 & 3 & 63 & 4 & 145 \\
\hline Total & 69 & 425 & 22 & 57 & 143 & 117 & 33 & 828 & 24 & 1718 \\
\hline
\end{tabular}

Legend: CH — Switzerland, DE - Germany, FI — Finland, GB — United Kingdom, NL — Netherlands, SE — Sweden, US — United States, JP — Japan.

Source: own work and calculations on the basis of an analysis of PCT patent documents. 


\section{Legend:}

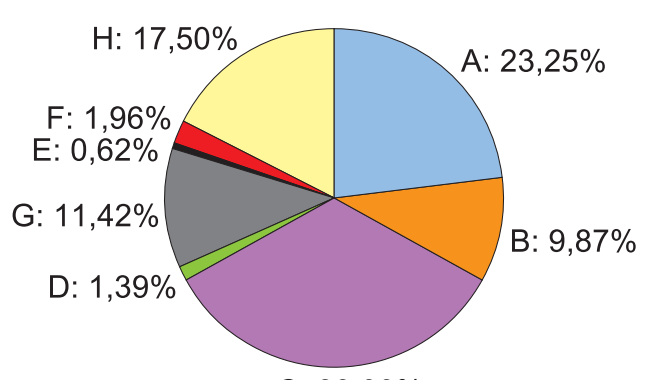

C: $33,99 \%$
A: Human necessities

B: Performing operations; Transporting

C: Chemistry; Metallurgy

D: Textiles; Paper

E: Fixed constructions

F: Mechanical engineering; Lighting; Heating; Weapons; Blasting

G: Physics

$\mathrm{H}$ : Electricity

Figure 3. The structure of PCT solutions authored or co-authored by immigrants from Poland, by area of technology according to the International Patent Classification (2004-2012)

Source: own work and calculations based on an analysis of PCT patent documents.

The above-mentioned results indicate that although mobile Poles contribute to increasing the innovative outputs of their host countries and thus, as may be supposed, increase the quality of life of their inhabitants, their role in this regard has been decreasing, at least in terms of the quantity (and not quality) of inventions.

Table 2. Structure of PCT inventions created by Poles in selected host countries, by area of technology according to the International Patent Classification (2004-2012)

\begin{tabular}{c|c|r|r|r|r|r|r|r|r}
\cline { 2 - 9 } & A & B & C & D & E & F & G & H & Total \\
\hline US & $36.44 \%$ & $3.85 \%$ & $30.91 \%$ & $0.43 \%$ & $0.62 \%$ & $1.12 \%$ & $9.87 \%$ & $16.76 \%$ & $100 \%$ \\
\hline DE & $13.33 \%$ & $14.96 \%$ & $46.12 \%$ & $1.94 \%$ & $0.15 \%$ & $1.86 \%$ & $6.51 \%$ & $15.13 \%$ & $100 \%$ \\
\hline GB & $22.09 \%$ & $15.72 \%$ & $29.38 \%$ & $0.91 \%$ & $0.68 \%$ & $5.01 \%$ & $12.53 \%$ & $13.68 \%$ & $100 \%$ \\
\hline NL & $16.20 \%$ & $3.17 \%$ & $11.27 \%$ & $0.70 \%$ & $0.00 \%$ & $0.35 \%$ & $42.60 \%$ & $25.71 \%$ & $100 \%$ \\
\hline CH & $26.79 \%$ & $6.70 \%$ & $39.23 \%$ & $0.00 \%$ & $0.48 \%$ & $8.13 \%$ & $10.05 \%$ & $8.62 \%$ & $100 \%$ \\
\hline FR & $11.58 \%$ & $25.87 \%$ & $42.47 \%$ & $5.02 \%$ & $4.25 \%$ & $0.00 \%$ & $4.63 \%$ & $6.18 \%$ & $100 \%$ \\
\hline SE & $16.48 \%$ & $0.00 \%$ & $10.99 \%$ & $0.00 \%$ & $0.00 \%$ & $0.00 \%$ & $21.98 \%$ & $50.55 \%$ & $100 \%$ \\
\hline FI & $0.00 \%$ & $2.00 \%$ & $0.00 \%$ & $0.00 \%$ & $0.00 \%$ & $6.00 \%$ & $16.00 \%$ & $76.00 \%$ & $100 \%$ \\
\hline JP & $3.19 \%$ & $12.76 \%$ & $15.96 \%$ & $9.57 \%$ & $0.00 \%$ & $0.00 \%$ & $14.89 \%$ & $43.61 \%$ & $100 \%$ \\
\hline
\end{tabular}

Legend: symbols from A to H: see Figure 3.

Source: own work and calculations based on the analysis of PCT patent documents.

Ekonomia - Wroclaw Economic Review 23/4 (2017)

(C) for this edition by CNS 


\section{Conclusions}

The increase in global flows of scientists, engineers, or high-class specialists in general, is more and more frequently accompanied by claims that international migration of human capital is beneficial only to host economies while the sending countries lose knowledge and skills of their emigrating citizens. As a result, the spatial mobility of talents contributes to the improvement of the quality of life of the inhabitants of developed countries — which enjoy the most interest among migrants - as well as the impoverishment of less-developed and developing countries which experience the mass outflow of the most valuable human capital. The countries which face mass emigration of their citizens include e.g., Poland, which upon accession to the EU gained better opportunities with regard to the movement of Poles both within and outside the borders of the EU.

In light of the above, the purpose of this paper is to determine what is the contribution of some of the most-educated mobile Poles (and more specifically creators of so-called international inventions) to improving the quality of life of their host countries. On the basis of the analysis of over 1700 international patent applications (PCT) it may be said that in the years 2004-2012 Poles, through their inventions, contributed to improving the quality of life of the inhabitants of their host countries. Considering, however, that the share of their inventions in the inventive output of their host countries ranged from $0.15 \%$ to $0.33 \%$, one can hardly conclude that the role of Poles in this area was much visible. Moreover, it has decreased since 2009.

Of the countries covered by the analysis, the greatest number of benefits from the presence of Poles have been enjoyed by the economies of the United States, Germany, and the United Kingdom, where immigrants from Poland created 828, 425, and 143 inventions, respectively. Meanwhile, in Japan, Sweden, and Finland the presence of Polish inventors translated into the quality of life of their inhabitants to a very small extent.

The results of the analysis undertaken in this work may be useful for further studies and might be supplemented by the assessment of the quality of inventions created by Poles abroad. As a result, it would be possible to more precisely determine the real contribution of Polish inventors to the improvement of the quality of life in developed countries which is determined not only by the very number but also the quality of new technical solutions. 


\section{References}

Edler J., Fier H., \& Grimpe C. (2011), "International scientist mobility and the locus of knowledge and technology transfer", Research Policy 40 (6), pp. 791-805.

Grabowska-Lusińska I., \& Okólski M. (2008), "Migracja z Polski po 1 maja 2004 r.: jej intensywność i kierunki geograficzne oraz alokacja migrantów na rynkach pracy krajów Unii Europejskiej", CRM Working Papers 33/91.

Hunt J. (2009), "Which immigrants are most innovative and entrepreneurial? Distinctions by entry visa", NBER Working Paper Series 14920.

Kaczmarczyk P. (2015), "Poland: Large migration outflows and skill-mismatch", in: Brain Drain - Brain Gain: European Labour Markets in Times of Crisis, ed. A. Schellinger, Bonn, pp. $33-43$.

Kerr W.R. (2009). "Breakthrough inventions and migrating clusters of innovation”, NBER Working Paper Series 15443.

Lee E.S. (1966), "A theory of migration”, Demography 3 (1), pp. 47-57.

Lesińska M. et al. (2014), Dekada członkostwa Polski w UE: społeczne skutki emigracji Polaków po 2004 roku, Warszawa.

Łotysz S. (2013), Wynalazczość polska w Stanach Zjednoczonych, Warszawa.

Miguelez E., \& Fink C. (2013), "Measuring the international mobility of inventors: A new database", WIPO Working Paper 8.

Niebuhr A. (2010), "Migration and innovation: Does cultural diversity matter for regional R\&D activity?", Papers in Regional Science 89 (3), pp. 563-585.

Oettl A., \& Agrawal A. (2008), "International labor mobility and knowledge flow externalities", Journal of International Business Studies 39, pp. 1242-1260.

Okólski M. (2009), "Polska jako aktor na europejskiej scenie migracyjnej”, in: Wspótczesne migracje: dylematy Europy i Polski, eds. M. Duszczyk, M. Lesińska, Warszawa, pp. 7-14.

Stephan P.E., \& Levin S.G. (2001), "Exceptional contributions to US science by the foreign-born and foreign-educated", Population Research and Policy Review 20 (1-2), pp. 59-79.

Wachowska M. (2017a), "Kierunki poakcesyjnej emigracji polskich wynalazców”, Studia i Prace WNEiZ Uniwersytetu Szczecińskiego 49/2, pp. 363-375.

Wachowska M. (2017b), "Przedsiębiorczość meksykańskiej mniejszości narodowej w Stanach Zjednoczonych, na podstawie liczby zgłoszeń patentowych PCT”, Przedsiębiorczość i Zarzadzanie XVIII (12), pp. 37-48.

Wachowska M. (2017c), "Wkład imigrantów z państw Europy Środkowo-Wschodniej w produkt innowacyjny Stanów Zjednoczonych. Wyniki badań”, Horyzonty Polityki 8 (23), pp. 77-99.

Ekonomia — Wroclaw Economic Review 23/4 (2017)

(C) for this edition by CNS 